\title{
Migrant Remittance Patterns in South Africa: A Micro-Level Analysis
}

\author{
Athenia Bongani Sibindi, Lindiwe Ngcobo \\ University of South Africa, Department of Finance, South Africa \\ sibinab@unisa.ac.za
}

\begin{abstract}
Migrant remittances increasingly constitute a significant source of financial inflows into emerging markets. Hitherto, extant studies have focused nearly exclusively on the macroeconomic benefits of remittances. Such studies have documented that the top benefits that accrue to the receiving country of remittances include: savings mobilisation, fostering intermediation, investment, sustenance of families and the enabling of access to health care and education by households who ordinarily would not afford to pay for these services. This study departs from the norm and investigated the migrant remittance patterns from a micro-level perspective by focusing on South Africa which is one of the top twenty remittance receiving countries in the world. The South Africa-National Income Dynamics Study dataset was employed in this study. Firstly, this study established that remittances constitute a significant source of income for households in South Africa. Secondly, it was established that the remittance variable is positively related to the household income variable and the result was highly statistically significant. Thirdly, the results of this study confirmed that the level of remittances is dependent on the level of education of the household member, with the inclination of the highly educated migrant worker to send more money to support their household. The South African government should consider as a policy instrument encouraging migrant workers in the diaspora to remit more money back into the country through the facilitation of ease of access of financial services.
\end{abstract}

Keywords: Migrant worker; household income; education; diaspora

\section{Introduction}

Migrant worker remittances into a country can inject the much-needed liquidity to stimulate economic activity. Remittances have increasingly become a great source of financial inflows outside foreign direct investments (FDI), for developing countries that have experienced high levels of emigration over the years (Sibindi, 2014). According to Ratha, Eigen-Zucchi and Plaza (2016), in 2015 worldwide remittances flows were estimated to be $\$ 601$ billion of which amount $\$ 441$ billion (nearly three times the value of official development assistance) was channelled to the developing countries. The importance of remittances is multifaceted. Firstly, they help foster the liquidity of financial markets. This results in the provision of more credit and hence enhancing the intermediation process. Secondly, remittances are a source of savings, with the migrant workers sending their money from the host country to their home country to save in their bank accounts for future consumption. Thirdly, migrant labor might invest in their home countries by channelling their remittances to invest in bonds, stocks or other such instruments. Fourthly, remittances are used to sustain families back in the recipient country. It could be that the breadwinner is the one who emigrated abroad in order to fend for the family and as such would then remit back the money to take care of the needs of the family, such as food, healthcare and education. Extant studies have been conducted to investigate the nexus between remittances and economic growth, or the relationship between remittances and financial development at a macro-level. Notwithstanding, to the best of the researchers' knowledge the remittance phenomenon has not been studied extensively at a micro-level.

The impetus behind selecting South Africa as a country of focus for this study is that it is one of the top remittance receiving countries in the world. South Africa received remittances of approximately $\$ 1$ billion in 2015 and ranked in the top of five African countries that received remittances (Ratha et al., 2016). As such, the motivation to explore the remittance patterns at a household level in South Africa was to unravel the dynamics behind such a distribution. The aim of this study was to establish the remittance patterns of South African migrant workers and to ascertain whether remittances constitute an important source of household income. Central to this study was to resolve the twin research questions: Does migrant worker remittance constitute a significant source of household income in South Africa? Is there a relationship between the level of education and the amount remitted? This study employed descriptive and inferential statistics analysis by utilizing the South African National Income Dynamic Study dataset. The results of this study confirmed that 
there is a positive relationship between household income and migrant worker remittances. A positive relationship was also documented to exist between the level of education and the quantum of remittances. The importance of such a study is that it can inform the ANC government as it crafts policy which is premised on the much vaunted 'radical economic social transformation' mantra. The policy imperatives that flow from this study are that the government must consider spending more on higher education and training in order to create an enabling environment for South Africans to attain a higher level of education. The government must also consider implementing policies that encourage the workers in the diaspora to send money back home. This can be achieved through the creation of an enabling environment that is unencumbered by unnecessary requirements and enhancing ease of access of financial services. The rest of the paper is arranged as follows: Section 2 reviews the related literature. Section 3 outlines the methodology used. Section 4 presents and discusses the empirical results and Section 5 concludes.

\section{Literature of Review}

The importance of migrant worker remittances is premised on the finance- economic growth nexus theory. Extant studies have been conducted that constitute the building blocks of the finance- economic growth theory. This theory can be can be traced to the seminal works of Schumpeter (1912) and later McKinnon (1973). Schumpeter (1912) postulated that financial institutions play a critical economic role in spurring technological innovation and economic activities. On the other hand, McKinnon (1973) contends that financial development is impeded by restrictive government regulations and economic interventions. Hitherto, extant studies that have interrogated the finance-growth nexus have mainly focused on the stock markets and the banking sector. There is limited research that focuses on the worker remittances-financial development nexus. Moreover, such studies have mainly focused on the macro-level benefits of remittances. The first strand of literature has been dedicated to establishing the relationship between remittances and economic growth (see for instance, Siddique, Selvanathan \& Selvanathan 2012; Jawaid, \& Raza, 2012 and Mundaca, 2009). Principally there are four hypotheses that have been tested from this vantage point. Firstly, whether remittances and economic growth are positively related? Secondly, whether remittances and economic growth are negatively related? Thirdly, whether there is a bi-directional relationship between remittances and economic growth.

Lastly, if there is no relationship between remittances and economic growth. In the majority of the documented studies any of the first three hypotheses have been validated. Among others, Salahuddin and Gow, (2015) examined the empirical link between remittances and economic growth by employing a panel of the largest remittances receiving countries namely; Bangladesh, India, Pakistan and Philippines for the period 1977 to 2012. They controlled for cross-sectional dependence for both variables and found that a positive relationship existed between remittances and economic growth in the long run. Bayar (2015) set out to determine if remittances have a significant impact on the economic growth in the transition economies of the European Union. He investigated the causality between economic growth, remittances and net FDI inflows for the period 1996 to 2013 by testing for causality. It was established that there is unidirectional causality running from remittances to economic growth as well as unidirectional causality running from net FDI inflows to economic growth. Bayar (2015) reasoned that remittances influenced economic growth by contributing to the national savings and meeting the foreign exchange requirements of the country partially. The second strand of literature focuses on the relationship between remittances and financial development (see for instance Aggarwal, Demirgüc-Kunt \& Perîa, 2011 and Brown, Carmignani, \& Fayad, 2013).

The relationships that have been documented to exist between remittances and financial development are analogous to those that exist between remittances and economic growth as enumerated in the foregoing. Karikari, Mensah and Harvey (2016) sought to establish whether remittances promoted financial development by employing a panel of 50 African countries for the period 1990 to 2011. They employed fixed effects and random effects models as well as a vector error correction model to estimate the relationship. Their results documented that remittances have a positive effect on financial development in the short-run but a negative effect in the long-run. Their results indicated that remittances positively and significantly influenced certain aspects of financial development such as bank deposits and money supply. Whereas, Coulibaly (2015) explored the causal link between remittances and financial development in Sub-Saharan African countries and the documented results were mixed. On the one hand, the results of their study 
corroborated the positive causal relationship running from remittances to financial development, for some of the countries namely; Niger, Sudan, Senegal and Sierra Leone. On the other, hand the causal relationship running from financial development to remittances was established only for Sudan.

Another strand of empirical studies has focused on probing the relationship between remittances, financial development and economic growth (see for instance Nyamongo, Misati, Kipyegon, \& Ndirangu, 2010 and Uddin, \& Sjö, 2013). Amongst other empirical studies, Guiliano and Ruiz-Arranz (2009) employed a sample of 100 developing countries to study the link between remittances, financial development and economic growth for the period 1975 to 2002. They found that remittances had promoted growth in less financially developed countries by providing an alternative way to finance investment. They reasoned that by becoming a substitute for inefficient or non-existent credit markets, remittances help alleviate credit constraints contributing to improve the allocation of capital and to boost economic growth. Similarly, Adenutsi (2011) examined the financial development-remittances-growth nexus in the case of Ghana by specifying a dynamic equilibrium-correction model for the period 1987 to 2007. The results documented that although financial development is detrimental to endogenous growth, it is crucial for mobilising remittances from international migrants. The results also revealed a bi-directional causality existing between financial development and international migrant remittances and a unidirectional causality running from remittances to economic growth. A growing body of studies has also been dedicated to examining the impact of remittances on human capital development.

The empirical evidence on the relationship between remittances and the level of education is rather mixed. On the one hand, a positive relationship is found to subsist between migrant remittances and the level of education of a recipient household member. Ngoma and Ismail (2013) examined the impact of migrant remittances on human capital formation in 89 developing countries using the GMM (generalised method of moments) estimator on aggregate level data between period 1970 and 2010. Their results reveal that migrant remittances have the potential to promote human capital formation among remittance recipients by alleviating income constraints and promoting more years of schooling at both the secondary and tertiary school levels. Salas (2014) investigated the effect of international migration on children left behind in Peru using a two-step estimation method by utilising data ranging from 2007 to 2010 . Their empirical results document that international remittances have a positive effect on the likelihood to send children to private schools controlling for absenteeism of parents. Naanwaab and Yeboah (2013) investigated the effect of migrant remittance on human capital investments by using a panel dataset comprising of 71 countries drawn from the World Bank's six regions of: East Asia and Pacific; Europe and Central Asia; Latin America and the Caribbean; Middle East and North Africa; South Asia and Sub-Saharan Africa using a systems approach.

They employed a three three-stage least squares regression with annual data ranging from 1998 and 2010. Their results showed that remittances have a positive impact on human capital development, specifically on educational and healthcare investment. On the other hand, a negative relationship is found to obtain between migrant remittances and the level of education of a recipient household member. For instance, the relationship between remittances and school attainment of household members left behind was examined by Kalaj (2015) who utilised cross-sectional data for Albania for the period 2002 to 2005 and estimated the Cox proportional hazard model. Their results documented that receiving remittances from household members working abroad increases the 'hazard' of leaving school after the completion of secondary education by a member of the recipient household. The foregoing demonstrates the importance of migrant worker remittances to an economy. Arguably these benefits cascade down to the micro (household) level.

\section{Research Methodology}

In this paper both descriptive and inferential statistics were employed to analyse the migrant remittances trends in South Africa. The Stata version 14 software was employed to analyse the data. The variables employed are discussed in the next sub-section.

Data Description and Variable Definition: In this study the National Income Dynamics Survey (NIDS) database was utilised. The wave 1 of 2008 NIDS dataset was employed. The wave 1 dataset was preferred as it also allowed the analysis to factor in the effects of the 2007 to 2009 global financial crises. The variables 
used in this study are summarised in the table below. The derived variable refers to the renamed variable as referred to in this study. In the first instance, hypotheses testing was conducted by applying inferential statistics. This study conducted a bivariate analysis to test the relationship between remittances and household income as well as to test the relationship between remittances and the level of education. The Pearson's chi-squared test was employed to test for the independence of the categorical variables in order to discern if a relationship exists in each instance.

Table 1: A Description of the Variables Used in this Study

\begin{tabular}{|c|c|c|}
\hline Name of Variable & Description of the Variable & Derived Variable \\
\hline $\begin{array}{l}\text { Remittances } \\
\text { (w1_hhremitt) }\end{array}$ & $\begin{array}{l}\text { This variable measures household monthly income from } \\
\text { remittances. }\end{array}$ & hhremitt \\
\hline $\begin{array}{l}\text { Household income } \\
\text { (w1_hhincome) }\end{array}$ & $\begin{array}{l}\text { This variable measures the household monthly income with } \\
\text { full imputations from other sources of income. }\end{array}$ & hhincome \\
\hline (w1_best_race) & $\begin{array}{l}\text { This variable measures the race of the respondent whether } \\
\text { African, white, coloured or Indian/Asian. }\end{array}$ & Race \\
\hline $\begin{array}{l}\text { Province } \\
\text { (w1_hhprov) }\end{array}$ & $\begin{array}{l}\text { This variable relates to the province where the respondent } \\
\text { resides. }\end{array}$ & hhprov \\
\hline $\begin{array}{l}\text { Highest education } \\
\left(w 1 \_r \_b 7\right)\end{array}$ & $\begin{array}{l}\text { This variable relates to the highest education achieved by a } \\
\text { household member. }\end{array}$ & hiedu \\
\hline
\end{tabular}

Quantitative Analysis: In this study the quantitative research approach was employed. Descriptive statistics were employed to illustrate the trends in household remittances in South Africa using demographic factors. The measures of central tendency that is; the mean, median and standard deviation were utilised to achieve this goal. The null hypotheses for this study are as specified as follows:

Hypothesis 1: Household income is not dependent on remittances Hypothesis 2: Remittances are not dependent on the level of education of the remitting member of the household.

Secondly, correlation analysis was conducted. In the last instance regression analysis was conducted to test the relationship between household income and remittances. The model is specified as follows:

hhincome $_{i}=$ hhremit $_{i}+\varphi_{i}$

where: hhincome $_{i}=$ average monthly household income for the $i$-th household

hhremit $_{i}=$ average monthly household remittances for the $i$-th household

$\varphi_{i}=$ error term

\section{Empirical Results}

In this section the empirical results of the study are presented and discussed. The descriptive statistics are presented first followed by inferential statistical analysis.

Descriptive Statistics: The summary statistics are presented in this section. Table 2 documents the distribution of household monthly income from remittances as well as total household monthly income. On average a household in South Africa received R1230 in remittances monthly. The median monthly remittance figure of R500 is a pittance as compared to the mean of R1230. Table 2 also documents the trends in the distribution of household income. The mean household monthly income is R4500 roughly as compared to the median value of R2065.

Table 2: A Summary of the Distribution of Household Remittances in 2008

\begin{tabular}{|c|c|c|c|c|}
\hline Variable & Mean & Median & $\begin{array}{l}\text { Standard } \\
\text { deviation }\end{array}$ & $\begin{array}{ll}\begin{array}{l}\text { Number } \\
\text { observations }\end{array} & \text { of } \\
\end{array}$ \\
\hline Remittances & $\mathrm{R} 1230$ & R500 & $\mathrm{R} 4456$ & 1046 \\
\hline Household income & $\mathrm{R} 4474$ & R2065 & R8041 & 7305 \\
\hline
\end{tabular}


The provincial distribution of remittances is documented in Figure 1. KwaZulu-Natal province receives the most remittances, accounting for $25.43 \%$, whereas Free State province receives the least remittances accounting for just close to $4 \%$ of the total. Eastern Cape Province is the second highest in the ranking accounting for close to $18 \%$ of the total. The trends in remittances received among the South African racial groups are documented in Figure 2. Africans accounted for the most of remittances sent with close to 69\%. The whites rank second receiving roughly $22 \%$ of the remittances. The coloureds are ranked third and the Indians/Asians rank last.

Figure 1: Provincial Distribution of Household Monthly Remittances in 2008

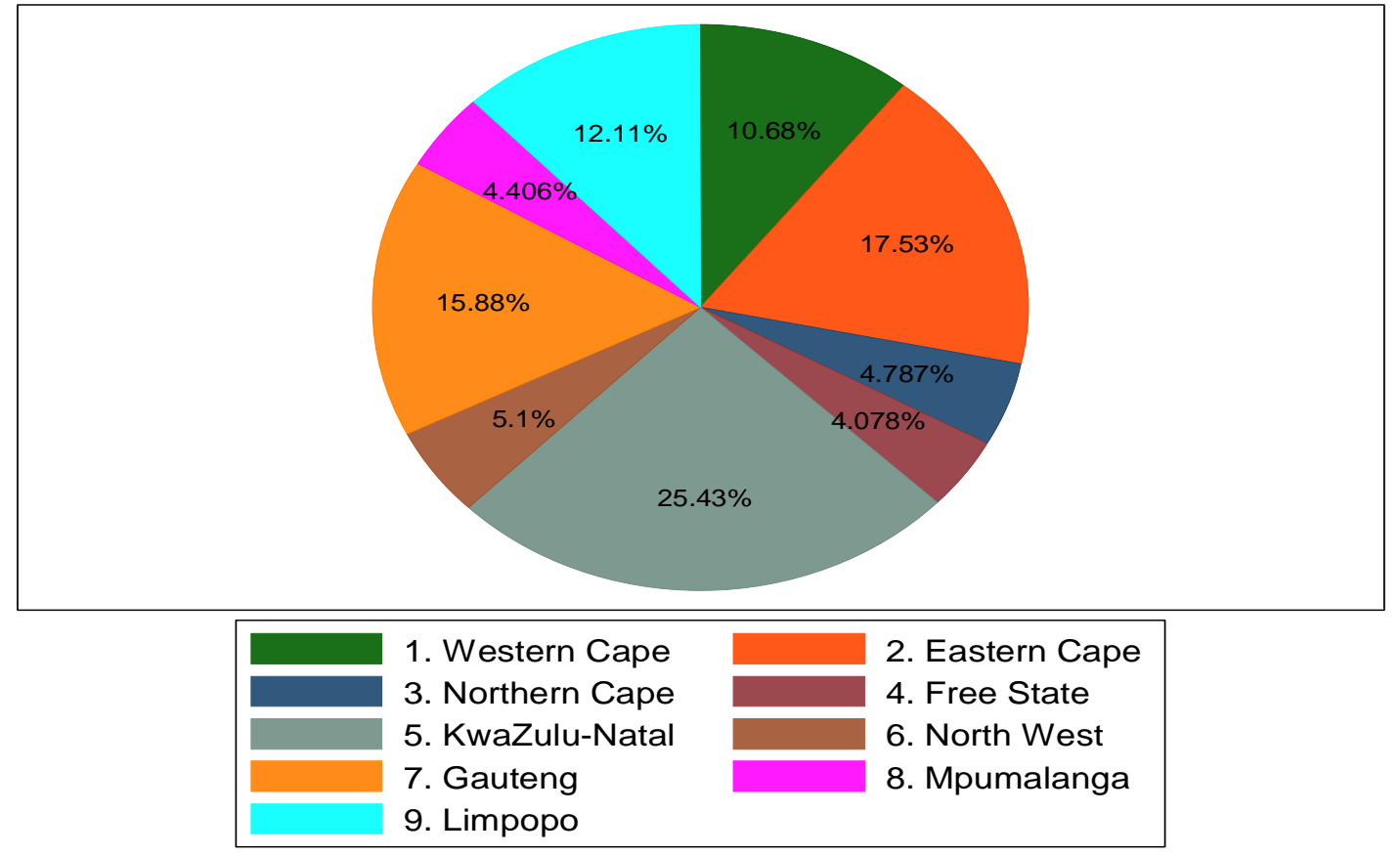

Figure 2: Distribution of Household Monthly Remittances among the Racial Groups in 2008

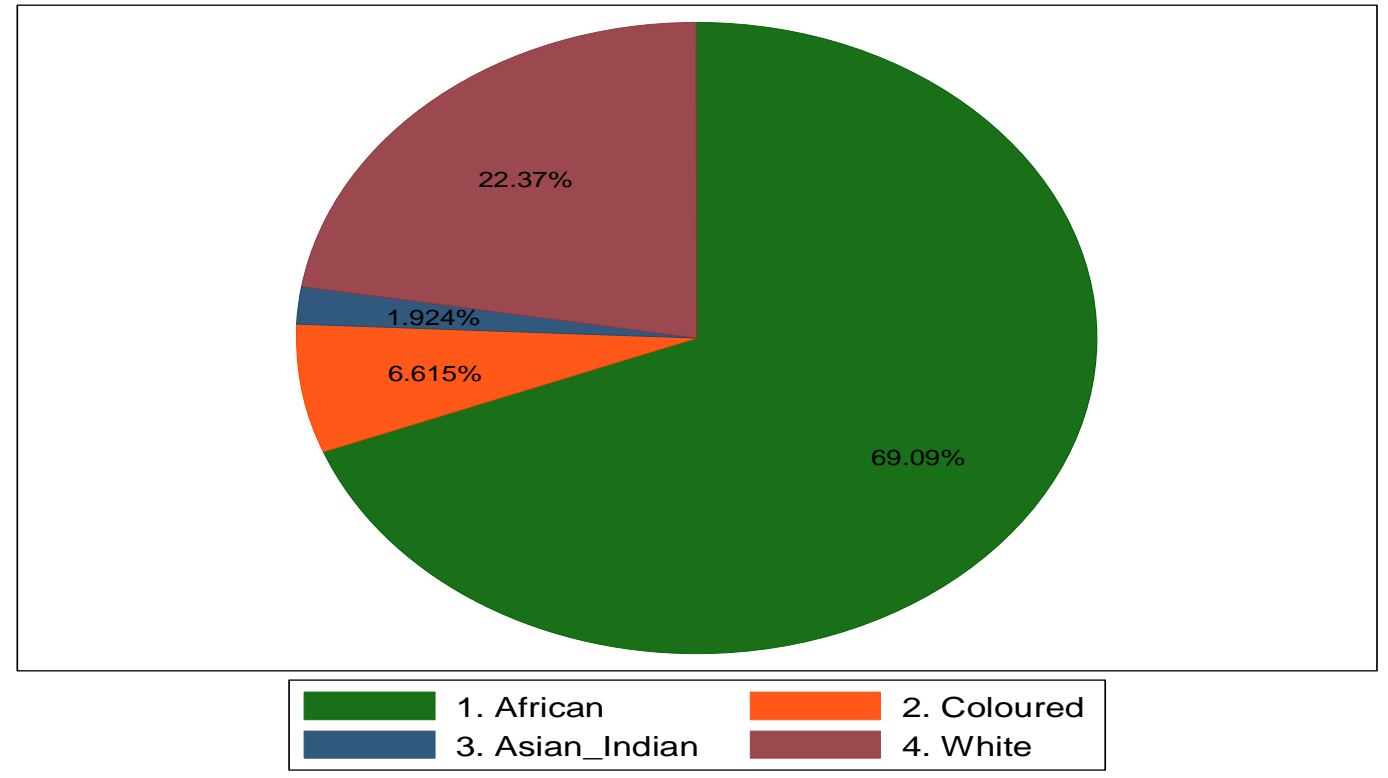




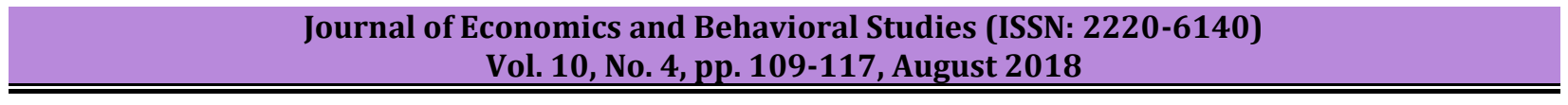

Table 3 presents the distribution of average household monthly remittances. On average a household in Gauteng province receive the highest monthly remittances of close to R2500 and a household in North West province receives the least with an average of roughly R863 per month. On average any household is South Africa receives an amount of R1230 in monthly remittances.

Table 3: The distribution of average household monthly remittances by province

\begin{tabular}{lc}
\hline Province & Average household monthly remittances (R) \\
\hline Eastern Cape & 1393 \\
Free State & 920 \\
Gauteng & 2491 \\
KwaZulu Natal & 1124 \\
Mpumalanga & 961 \\
North West & 863 \\
Northern Cape & 1044 \\
Western Cape & 1387 \\
Average & 1230 \\
\hline
\end{tabular}

Table 4: Trends in monthly household remittances and the level of education attained

\begin{tabular}{lc}
\hline Level of education & Average household monthly remittances (R) \\
\hline No schooling & 1005 \\
Grade 1 & - \\
Grade 2 & 500 \\
Grade 3 & 630 \\
Grade 4 & 575 \\
Grade 5 & 494 \\
Grade 6 & 550 \\
Grade 7 & 1871 \\
Grade 8 & 762 \\
Grade 9 & 1455 \\
Grade 10 & 1130 \\
Grade 11 & 1020 \\
Grade 12 & 1683 \\
National Technical Certificate 1 & 500 \\
National Technical Certificate 2 & 1875 \\
National Technical Certificate 3 12 & 550 \\
Certificate with less than grade 12 & 1980 \\
Diploma with less than grade 12 & 2085 \\
Certificate with grade 12 & 1270 \\
Bachelor degree & 1697 \\
Bachelor degree and diploma & 2644 \\
Honours degree & 1175 \\
Higher degree (Masters or doctorate) & 2033 \\
Other & 1700 \\
Average & 1230 \\
\hline
\end{tabular}

Inferential Analysis: In the first instance, a bivariate analysis was conducted to determine if there was any significant relationship between remittances and the highest level of education attained by a household member. The results are presented in the Tables 5. The null hypothesis of the independence of the remittances variable from the education variable is rejected in favour of the alternative hypotheses of a significant relationship subsisting between the remittances and education variable. The Pearson's chisquared statistic is significant at the $1 \%$ level of significance. 
Table 5: Remittances and level of education contingency table

\begin{tabular}{|c|c|c|c|c|}
\hline \multirow[t]{2}{*}{ Categorical level of education variable } & \multicolumn{3}{|c|}{$\begin{array}{l}\text { Categorical remittances variable } \\
\text { (low, medium and high) }\end{array}$} & \multirow[t]{2}{*}{ Tota } \\
\hline & R0-R500 & R501-R1000 & R1001+ & \\
\hline No schooling & 66 & 31 & 26 & 123 \\
\hline Grade 1 & 3 & 0 & 2 & 5 \\
\hline Grade 2 & 7 & 2 & 2 & 11 \\
\hline Grade 3 & 11 & 10 & 3 & 24 \\
\hline Grade 4 & 26 & 7 & 5 & 38 \\
\hline Grade 5 & 20 & 9 & 3 & 32 \\
\hline Grade 6 & 33 & 5 & 7 & 45 \\
\hline Grade 7 & 46 & 21 & 16 & 83 \\
\hline Grade 8 & 47 & 14 & 24 & 85 \\
\hline Grade 9 & 57 & 20 & 18 & 95 \\
\hline Grade 10 & 66 & 21 & 31 & 118 \\
\hline Grade 11 & 81 & 28 & 33 & 142 \\
\hline Grade 12 & 85 & 41 & 57 & 183 \\
\hline National Technical Certificate 1 & 2 & 0 & 0 & 2 \\
\hline Certificate with less than grade 12 & 0 & 1 & 3 & 4 \\
\hline Diploma with less than grade 12 & 1 & 0 & 1 & 2 \\
\hline Certificate with grade 12 & 12 & 2 & 3 & 17 \\
\hline Diploma with grade 12 & 3 & 8 & 10 & 21 \\
\hline Bachelor degree & 4 & 1 & 3 & 8 \\
\hline Bachelor degree and diploma & 0 & 1 & 2 & 3 \\
\hline Honours degree & 0 & 0 & 1 & 1 \\
\hline Total & 570 & 222 & 250 & 1042 \\
\hline \multicolumn{5}{|c|}{ Pearson's chi-squared $(40)=68.48$ Probability $=0.003$} \\
\hline
\end{tabular}

In the second instance bivariate analysis was conducted to determine if there was any significant relationship between the remittances and the household income variables. The results are documented in Table 6. Similarly, the null hypothesis of the independence of household income on the remittances is rejected in favour of a relationship subsisting between household income and remittances. The Pearson's test statistic is highly significant at the $1 \%$ level of significance.

Table 6: Household income and remittances contingency table

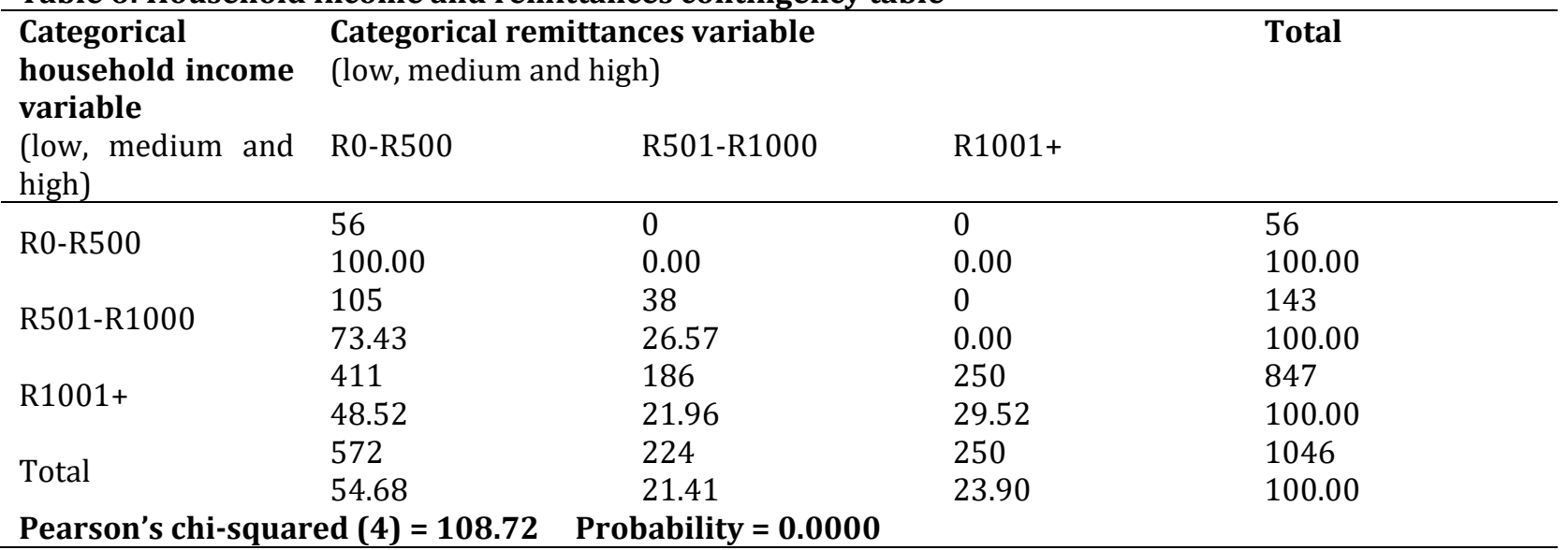

The correlation matrix of the variables of interest is documented in Table 7. The household variable is highly correlated to the remittances variable which is further evidence of the strong relationship that exists between household income and remittances. Education is lowly correlated to the remittance as well as the income variables. 
Table 7: Correlation Matrix

\begin{tabular}{llll}
\hline Variable & Household income & Remittances & Level of education \\
\hline Household income & 1.0000 & & \\
Remittances & 0.6355 & 1.0000 & \\
Level of education & 0.0645 & 0.0308 & 1.0000 \\
\hline
\end{tabular}

Finally, a linear regression model was estimated with the household income variable regressed on the remittances variable. The results are documented in Table 8. It was established that the remittances variable is positively related to the household income variable and the results is highly statistically significant at the $1 \%$ level of significance.

Table 8: Regression Analysis

\begin{tabular}{llll}
\hline household income & coefficient & t-statistic & p-value \\
\hline Remittances & 1.052 & 26.5 & 0.000 \\
Constant & 200.9 & 5.24 & 0.000 \\
Adjusted R-squared & 0.4047 & & \\
F-statistic & 354.87 & & \\
Number of observations & 1042 & & \\
\hline
\end{tabular}

\section{Conclusion and Policy Recommendations}

The present article seeks to establish the relative importance of remittances at a micro-level in South Africa. It was demonstrated that remittances constitute a significant source of income for households in South Africa. Their importance is highest amongst the African households and the least amongst the Indian households. Further, it was established that KwaZulu-Natal Province receives the most remittances, accounting for 25.43\%, whereas Free State Province receives the least remittances accounting for just close to $4 \%$ of the total. It was also demonstrated that household income is dependent on migrant worker remittance. Further it was also established that the quantum of remittances is dependent on the level of education of the household member who is remitting. Though not strong, it seems that there is a weak relationship between the level of education attained by a member of a household and the level of remittances received. We have reason to believe that the highly educated the migrant worker, the more they can afford to remit. In light of the foregoing, it is imperative that by way of policy advice, the South African government pursue policies that will further buttress migrant worker remittances. Arguably, promoting access to financial services and the streamlining of regulations can be a viable policy instrument that will induce inward remittances into South Africa. The other policy instrument to consider is to create an environment that facilitates the attainment of tertiary education. Arguably, with higher levels of educational attainment, South African labour would become competitive in the diaspora and hence incentivising migration. The higher the level of education of the migrant labour, the higher the level of remittances they will be able to channel back to the South African economy.

\section{References}

Adenutsi, D. E. (2011). Financial development, international migrant remittances and endogenous growth in Ghana. Studies in Economics and Finance, 28(1), 68-89.

Aggarwal, R., Demirgüç-Kunt, A. \& Pería, M. S. M. (2011). Do remittances promote financial development? Journal of Development Economics, 96(2), 255-264.

Bayar, Y. (2015). Impact of Remittances on the Economic Growth in the Transitional Economies of the European Union. Economic Insights-Trends \& Challenges, 67(3), 1-10.

Brown, R. P., Carmignani, F. \& Fayad, G. (2013). Migrants' Remittances and Financial Development: Macro-and Micro-Level Evidence of a Perverse Relationship. The World Economy, 36(5), 636-660.

Coulibaly, D. (2015). Remittances and financial development in Sub-Saharan African countries: A system approach. Economic Modelling, 45, 249-258.

Giuliano, P. \& Ruiz-Arranz, M. (2009). Remittances, financial development and growth. Journal of Development Economics, 90(1), 144-152. 


\section{Journal of Economics and Behavioral Studies (ISSN: 2220-6140)}

Vol. 10, No. 4, pp. 109-117, August 2018

Jawaid, S. T. \& Raza, S. A. (2012). Workers' remittances and economic growth in China and Korea: an empirical analysis. Journal of Chinese Economic and Foreign Trade Studies, 5(3), 185-193.

Kalaj, E. H. (2015). Effects of remittance flows on the school attainment of household members left behind. Academic Journal of Interdisciplinary Studies, 3(6), 527.

Karikari, N. K., Mensah, S. \& Harvey, S. K. (2016). Do remittances promote financial development in Africa? Springer Plus, 5(1), 1-21.

McKinnon, R. I. (1973). Money and capital in economic development. Brookings Institution Press.

Mundaca, B. G. (2009). Remittances, financial market development, and economic growth: the case of Latin America and the Caribbean. Review of Development Economics, 13(2), 288-303.

Naanwaab, C. \& Yeboah, O. A. (2013). Migrant remittances and human capital investments. Review of Applied Socio-Economic Research, 6(2), 191-202.

Ngoma, A. L. \& Ismail, N. W. (2013). Do migrant remittances promote human capital formation? Evidence from 89 developing countries. Migration and Development, 2(1), 106-116.

Nyamongo, E. M., Misati, R. N., Kipyegon, L. \& Ndirangu, L. (2012). Remittances, financial development and economic growth in Africa. Journal of Economics and Business, 64(3), 240-260.

Ratha, D., Eigen-Zucchi, C. \& Plaza, S. (2016). Migration and Remittances Factbook 2016. World Bank Publications.

Salahuddin, M. \& Gow, J. (2015). The relationship between economic growth and remittances in the presence of cross-sectional dependence. The Journal of Developing Areas, 49(1), 207-221.

Salas, V. B. (2014). International remittances and human capital formation. World Development, 59, 224-237.

Schumpeter, J. A. (1912). The theory of economic development, Joseph Alois Schumpeter, 61-116.

Sibindi, A. B. (2014). Remittances, financial development and economic growth: empirical evidence from Lesotho. Journal of Governance and Regulation, 3(4),116-124.

Siddique, A., Selvanathan, E. A. \& Selvanathan, S. (2012). Remittances and economic growth: empirical evidence from Bangladesh, India and Sri Lanka. Journal of Development Studies, 48(8), 1045-1062.

Uddin, G. S. \& Sjö, B. (2013). Remittances, financial development and economic growth in Bangladesh. South Asia Economic Journal, 14(2), 261-273. 